\title{
Activities of in vitro laboratory of National Institute of Nuclear Medicine and Allied Sciences
}

\author{
Israque Hossain Ansari, Mizanul Hasan, Mohammad Anwar-Ul Azim, Sakera Khatun, \\ Haroun-or-Rashid, Zakir Hossain, Mustafa Mamun. \\ National Institute of Nuclear Medicine and Allied Sciences \\ Correspondence: Md. Israque Hossain Ansari, Principle Scientific Officer, Block-D, $7^{\text {th }}-10^{\text {th }}$ floor, NINMAS, \\ BSM Medical University (IPGMR) campus, Shahbag, Dhaka-1000. \\ E-mail: israque_h@yahoo.com, Telephone: 02-861957
}

\begin{abstract}
The in vitro laboratory of radioimmunoassay (RIA) Division is designed to provide clinical diagnostic service (e.g. hormone assay) and also to facilitate research works related to radioimmunoassay. The in-vitro laboratory is situated at the $9^{\text {th }}$ floor of block-D of Bangabandhu Sheikh Mujib Medical University (BSMMU). Presently the invitro division of National Institute of Nuclear Medicine and Allied Sciences (NINMAS) has 18 man powers including doctors, radiochemists, officers, technologists and other laboratory staffs. The equipments used for RIA in in vitro laboratory are gamma counter, micropipettes, centrifuge, magnetic separators, vortex mixture, incubator/water bath, stirrers, deep freezer, refrigerator, pH Meter, analytical balance, test tubes and laboratory glassware etc.
\end{abstract}

A large number of samples are analyzed by the RIA Lab each week. In the year $2013-2014\left(1^{\text {st }}\right.$ July $2013-30^{\text {th }}$ June 2014), a total of 100 assays were done. A total of 25135 samples were assayed by RIA/IRMA in the in vitro lab. Results are reported on every Monday and Thursday of the week.

After careful consideration of the local infrastructure, robustness and cost of nuclear and non-nuclear assays, it is likely that RIA methodology will be the main workhorse of routine laboratory diagnostic services of NINMAS.

Key Words: NINMAS, In-vitro laboratory, Radioimmunoassay

\section{INTRODUCTION}

Institute of Nuclear Medicine was first established in 1980 on $1^{\text {st }}$ and $3^{\text {rd }}$ floor of Block-A of the former Institute of Post Graduate Medicine and Research (IPGMR). In 1982, the in vitro laboratory was started in the $1^{\text {st }}$ floor. At that time thyroid and its related hormone T3, T4 and TSH were done manually. The kits were purchased from the

Amersham International plc, Amersham UK. Very few samples $<50$ were done in a week. The standards, samples, tracers and antibodies were pipette by micropipette and results were found out by counting in a scalar rate meter and plotting on a graph paper manually. Later on in 1984, a programmable calculator was used to find out the results. After that Dudley automatic gamma counter and then PC based Oakfield gamma counter \& Berthold gamma counters were used.

In 2006 the institute was shifted in the newly constructed 18 storied Block-D of Bangabandhu Sheikh Mujib Medical University (BSMMU) with about 60,000 sft space comprising four floor levels $\left(7^{\text {th }}-10^{\text {th }}\right.$ floor). The in vitro lab is now situated in the $9^{\text {th }}$ floor of the Institute. The Institute in this newly constructed building was named as the Institute of nuclear medicine and ultrasound (INMU). The parameter of hormone estimation was increased by purchasing China Kits from 2005. Now about 20 hormones were estimated by using China kits. All hormones were done by RIA except TSH, which was done by IRMA. Now PC based RIA Counters (STRATEC - Germany) were used.

Along with the hormone radioimmunoassayassay, RBC life span, RBC mass, blood volume, sequestration study and vitamin B-12 malabsorption study were also done from 1985 in the in-vitro laboratory of the Institute. But due to unavailability of Cr-51 sodium chromate and Dicopac kits, at present the tests were not performed at NINMAS.

In 2013, automated RIA instrument using antibody coated tube kits, was introduced in the in vitro laboratory of National Institute of Nuclear medicine and Allied Sciences (NINMAS).

The in vitro laboratory is situated in the $9^{\text {th }}$ floor of the newly constructed building of Block-D of 
Bangabandhu Sheikh Mujib Medical University (BSMMU). The laboratory consists of two separate rooms, (Room No. - 1005 and 1012).

Most major items of equipment required for in-vivo function studies such as red blood cell (RBC) labeling, blood and plasma volume measurement and the Schilling test are available at In-vitro laboratories, in-vivo nuclear medicine units. These in-vivo procedures are carried out in sterile techniques.

\section{Table 1: List of equipments of in the laboratory}

\begin{tabular}{|c|c|}
\hline Item & Description \\
\hline Automated system & (Quantity: One) \\
\hline a) Dispenser & Auto dispense up to 600 tubes, with Computers. \\
\hline b) Stirrer & Stir 600 tubes at a time. \\
\hline c) Washer & Aspirate/wash 20 tubes at a time continuously. \\
\hline d) Gama Counter & Multiple auto, 10 Channels, with Computers. \\
\hline Gamma counter & $\begin{array}{l}\text { Multiple manual, } 12 \text { Channels, with Computers. } \\
\text { (Quantity: Four) }\end{array}$ \\
\hline Gamma counter & Single well manual.( Quantity: One) \\
\hline $\begin{array}{llll}\text { RIA Pipettes } & \text { and } & \text { tips } & (\mu \\
\text { Pipettes) }\end{array}$ & $\begin{array}{l}\text { Semi-automatic, hand-held, } 20-1000 \mu 1 \text { capacity. } \\
\text { (Quantity: Ten) }\end{array}$ \\
\hline Centrifuge & Refrigerated, for RIA tubes. (Quantity: Five) \\
\hline Centrifuge & Normal, for blood separating. (Quantity: Two) \\
\hline Stirrers & Two \\
\hline Vortex mixture & Two \\
\hline Magnetic separator & Ten \\
\hline Incubator & For incubation of RIA tubes at $37^{\circ} \mathrm{C}$. (Quantity: Five) \\
\hline Water bath & 6L capacity. (Quantity: One) \\
\hline Deep freezer & Cupboard type, to $-20^{\circ} \mathrm{C}$. (Quantity: Three) \\
\hline Refrigerator & Upright, (Quantity: Seven) \\
\hline PH meter & $\begin{array}{l}\text { General purpose type bench top with standard } \\
\text { electrolytes. (One) }\end{array}$ \\
\hline Analytical balance & Sensitive to $0.1 \mathrm{mg}$. (One) \\
\hline Distilled water still & $2 \mathrm{~L} / \mathrm{h}$ capacity. (One) \\
\hline $\begin{array}{l}\text { Laboratory glass ware, test tubes } \\
\text { etc. }\end{array}$ & \\
\hline
\end{tabular}

Table 2: Manpower in In-vitro division of NINMAS

\begin{tabular}{|l|l|l|l|l|l|l|l|l|l|l|}
\hline Position & CMO & PSO & SSO & EO & JEO & SSA & SA-I & SA-II & LA & Daily basis \\
\hline Number & 1 & 1 & 1 & 3 & 1 & 2 & 3 & 3 & 2 & 1 \\
\hline
\end{tabular}

Table 3: Parameters a analyzed and their frequency

\begin{tabular}{|l|c|c|l|}
\hline $\begin{array}{l}\text { Hormone } \\
\text { analyzed }\end{array}$ & $\begin{array}{l}\mathrm{T}_{3}, \mathrm{~T}_{4}, \mathrm{TSH}, \\
\mathrm{FT}_{3}, \mathrm{FT}_{4}\end{array}$ & $\mathrm{TG}$ & $\begin{array}{l}\text { TMAb, TGAb, TPOAb, LH, FSH, Testosterone, } \\
\text { Progesterone, Prolactin, Estradiol, PSA, } \\
\text { Calcitonin, Cortisol, PTH }\end{array}$ \\
\hline $\begin{array}{l}\text { No. of assays } \\
\text { per week }\end{array}$ & Three & Four & \multicolumn{2}{|c|}{ One } \\
\hline
\end{tabular}

\section{Table 4: No of patients analyzed for individual}

\section{Assays (2013-2014)}

\begin{tabular}{|c|c|c|c|c|c|c|c|}
\hline $\begin{array}{l}\text { Total } \\
\text { Assay }\end{array}$ & $\begin{array}{l}\text { Total } \\
\text { Patients }\end{array}$ & \multicolumn{6}{|c|}{ Individual Patients } \\
\hline \multirow[t]{3}{*}{100} & \multirow[t]{3}{*}{25135} & $\begin{array}{c}T_{3} \\
3884\end{array}$ & $\begin{array}{c}\mathrm{T}_{4} \\
4617\end{array}$ & $\begin{array}{c}\mathrm{FT}_{3} \\
5463\end{array}$ & $\begin{array}{c}\mathrm{FT}_{4} \\
11685\end{array}$ & $\begin{array}{l}\text { TSH } \\
23055\end{array}$ & $\begin{array}{c}\text { TG } \\
4112\end{array}$ \\
\hline & & $\begin{array}{c}\text { TMAb } \\
6\end{array}$ & $\begin{array}{l}\text { TGAb } \\
25133\end{array}$ & $\begin{array}{c}\text { TPOAb } \\
1102\end{array}$ & $\begin{array}{l}\text { LH } \\
618\end{array}$ & $\begin{array}{l}\text { FSH } \\
648\end{array}$ & $\begin{array}{c}\text { Testosterone } \\
359\end{array}$ \\
\hline & & $\begin{array}{c}\text { Progesterone } \\
31\end{array}$ & $\begin{array}{c}\text { Prolactin } \\
688\end{array}$ & $\begin{array}{c}\text { Estradiol } \\
123\end{array}$ & $\begin{array}{c}\text { PSA } \\
42\end{array}$ & $\begin{array}{c}\text { Cortisol } \\
54\end{array}$ & $\begin{array}{l}\text { PTH } \\
42\end{array}$ \\
\hline
\end{tabular}

\section{Graphical presentation:}

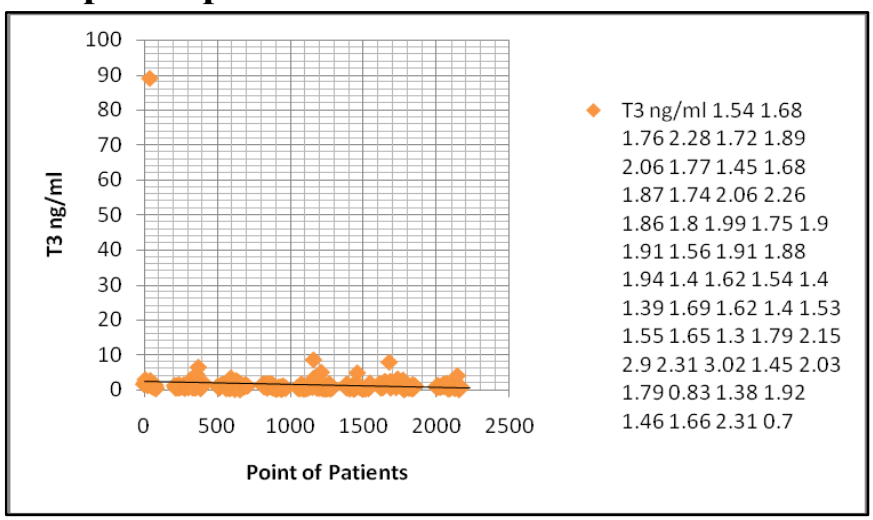

Figure1. $T_{3}$

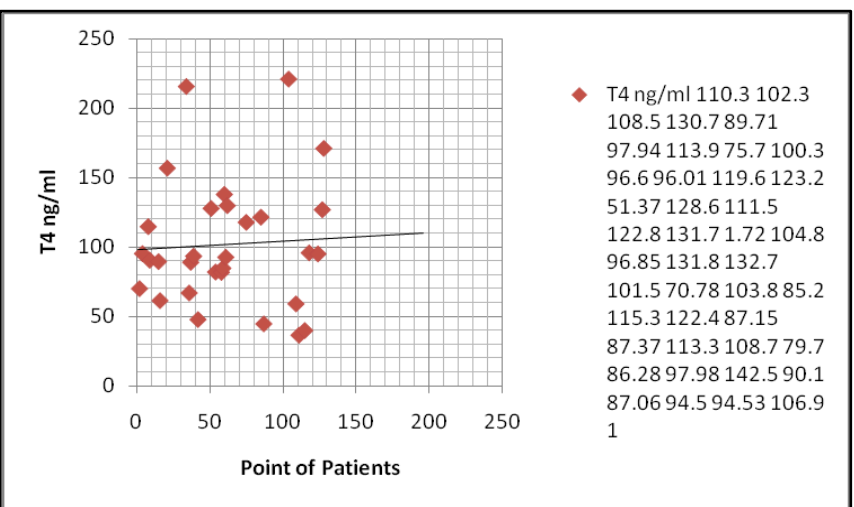

Figure 2. $\mathbf{T}_{4}$

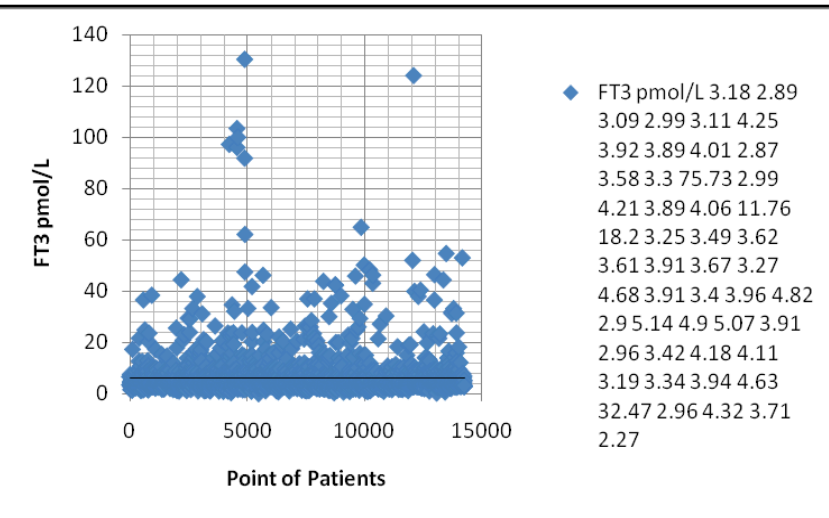

Figure 3. $\mathrm{FT}_{3}$

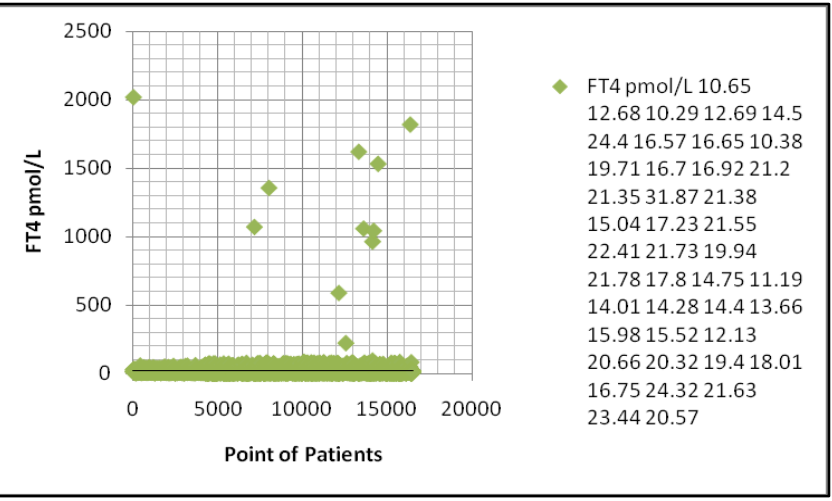

Figure 4. FT $_{4}$ 


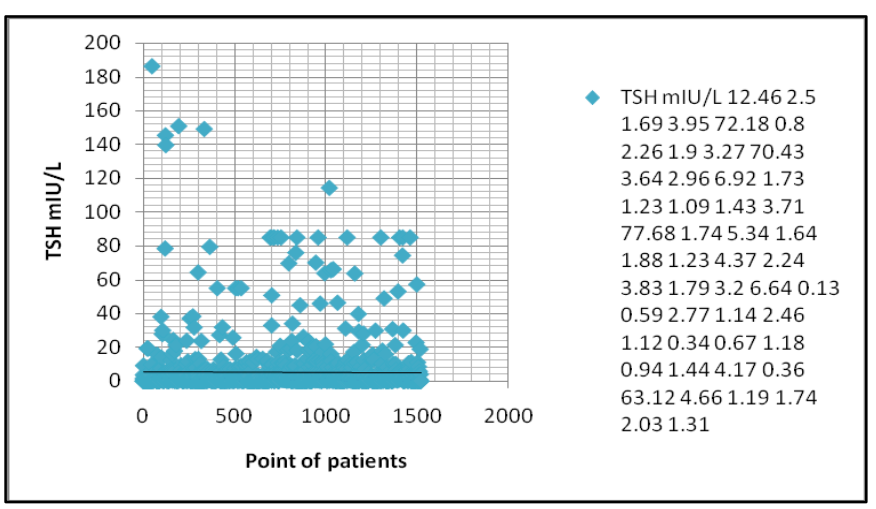

Figure 5. TSH

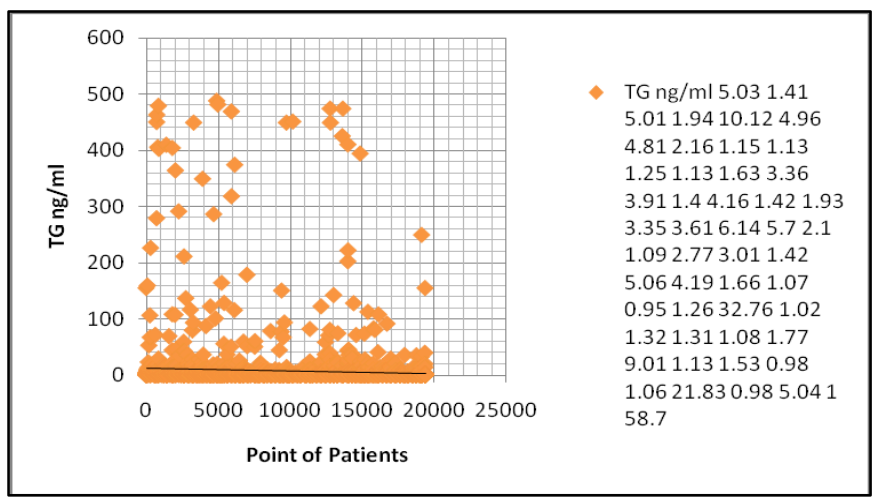

Figure 6. TG

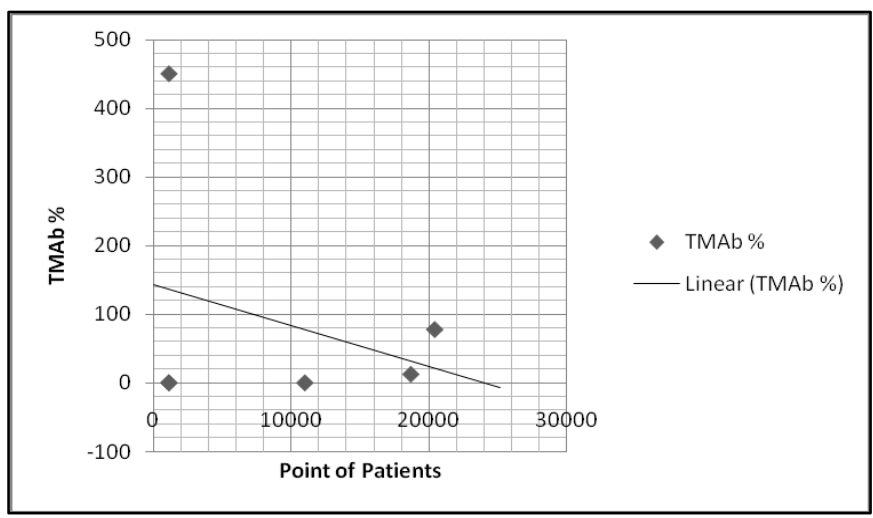

Figure 7. TMAb

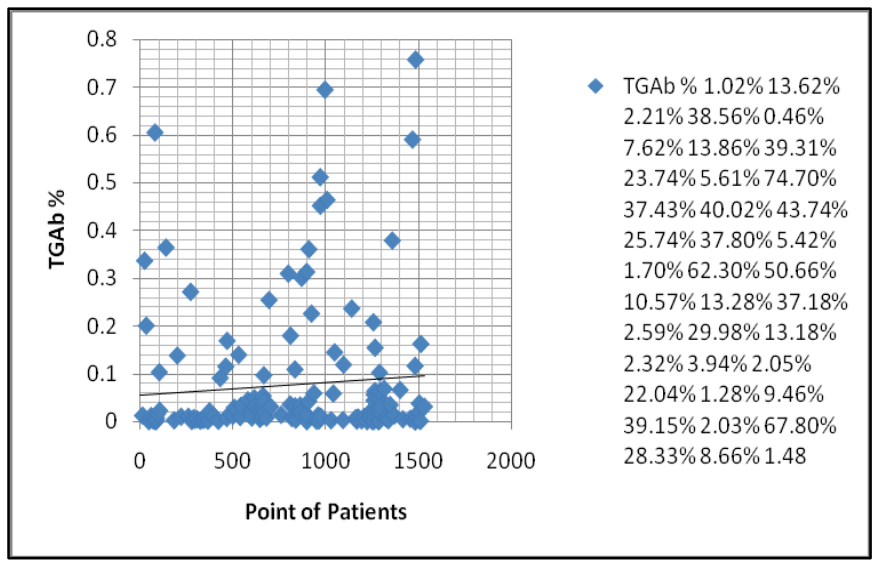

Figure 8. TGAb

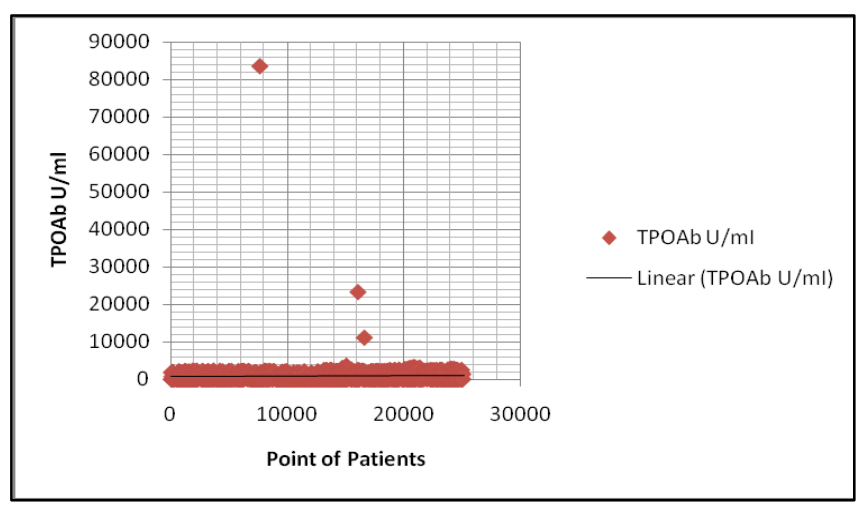

Figure 9. TPOAb

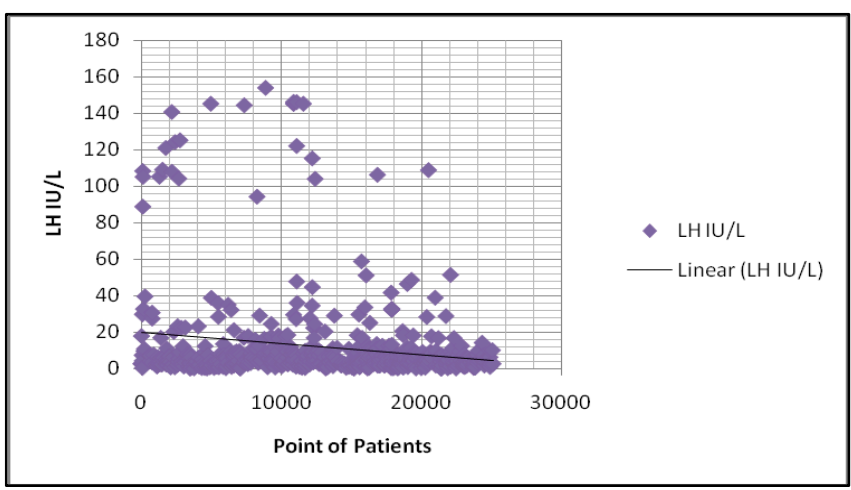

Figure 10. LH

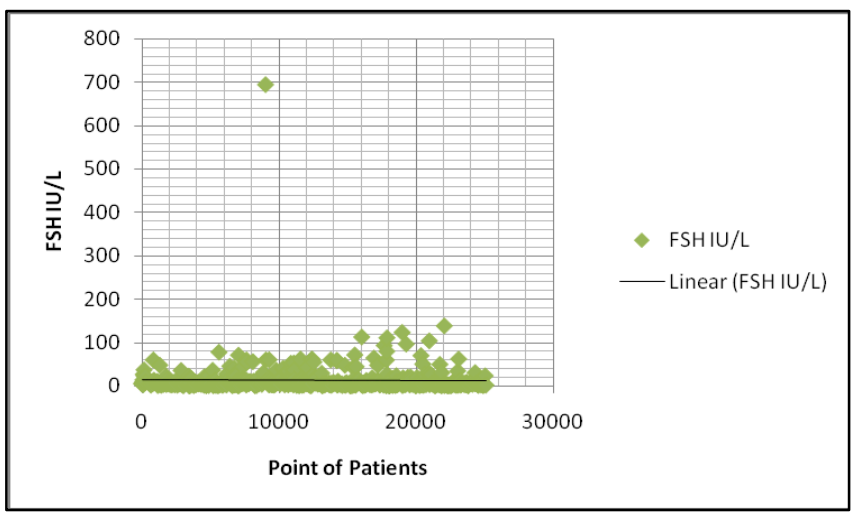

Figure 11. FSH

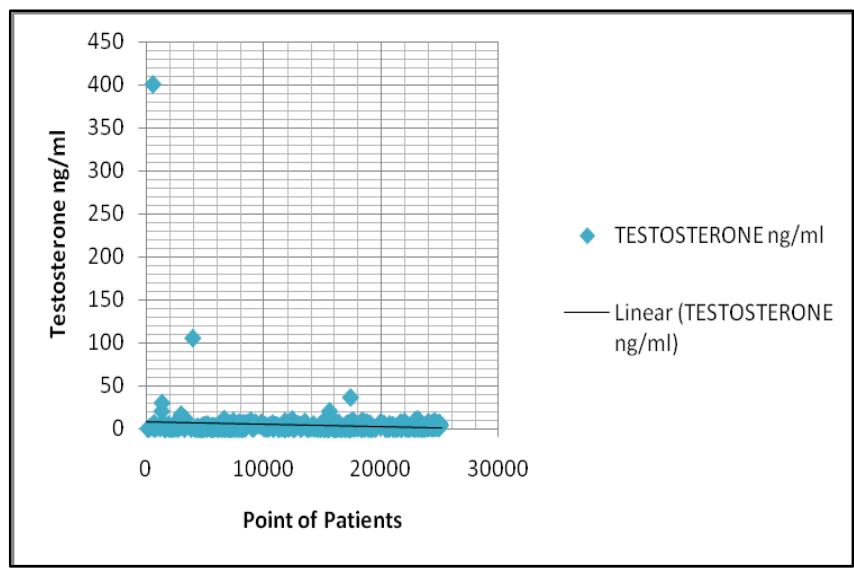

Figure 12. Testosterone 


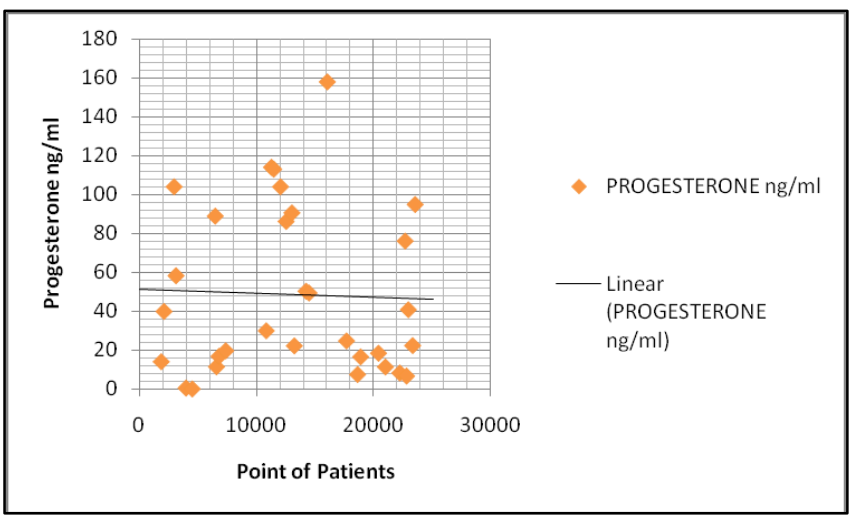

Figure 13: Progesterone

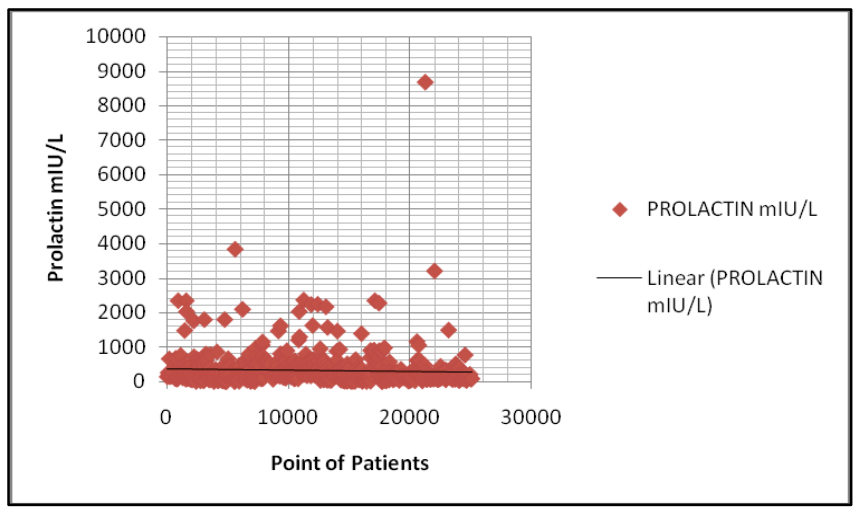

Figure 14: Prolactin

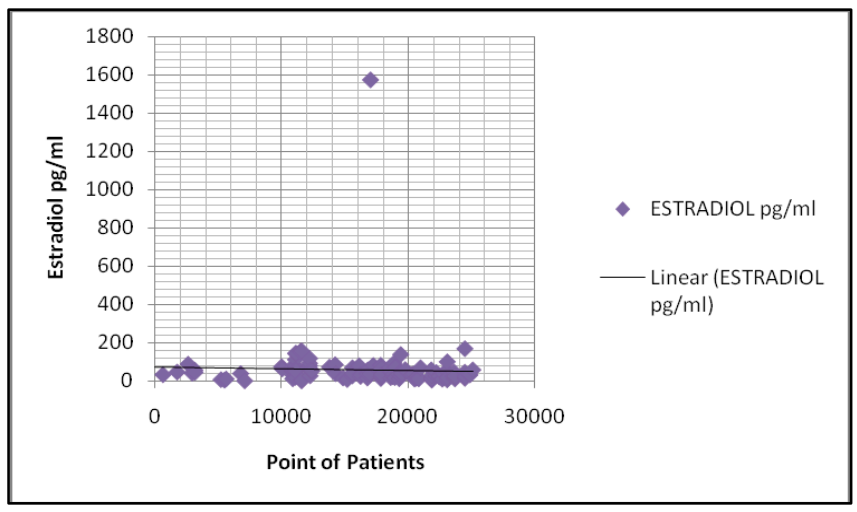

Figure 15: Estradiol

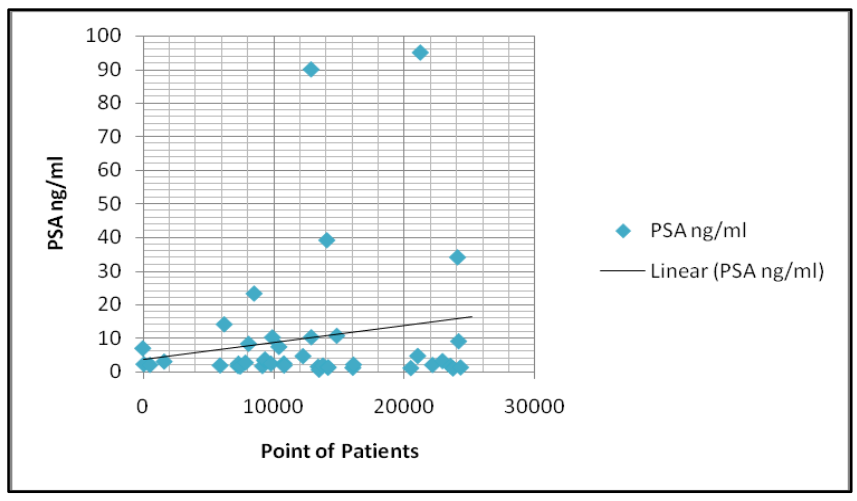

Figure 16: PSA

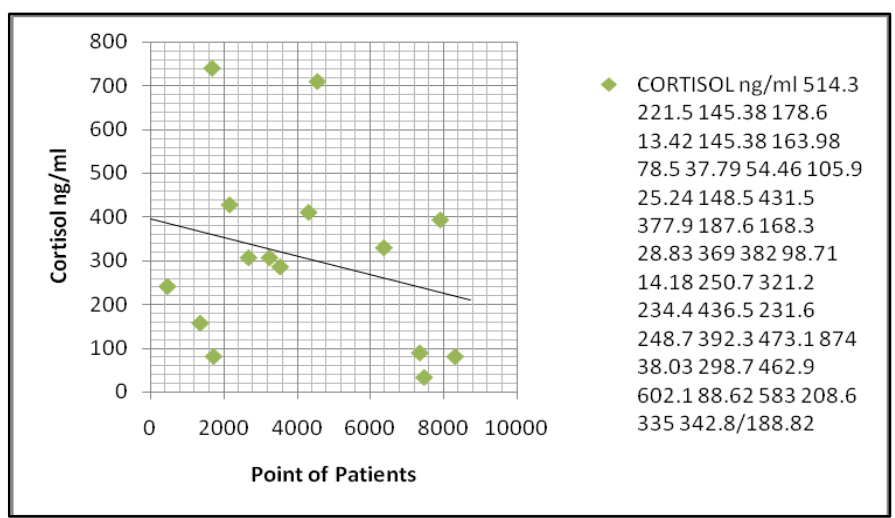

Figure 17. Cortisol

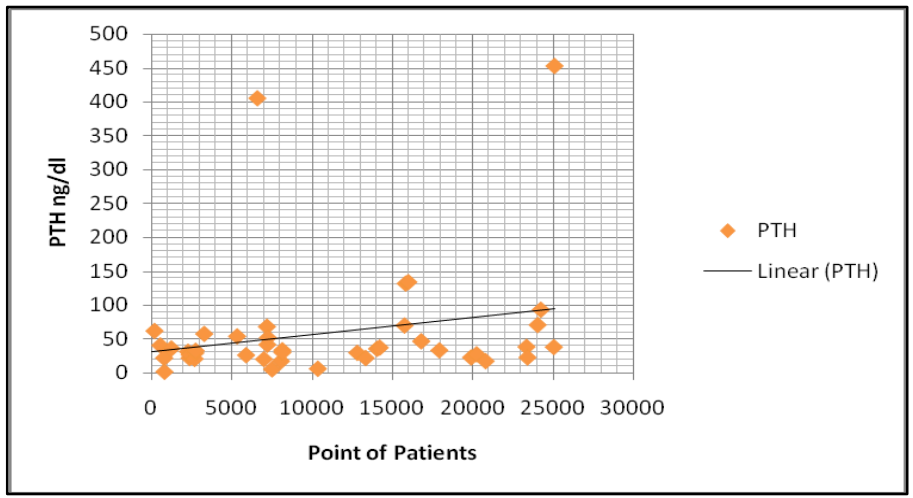

Figure 18. PTH

\section{DISCUSSION}

A fair number of samples are analyzed in the RIA lab each week. Results are reported on every Monday and Thursday of the week. The patient's blood samples are collected every day. The collection of Sunday and Monday are reported on next Monday and collection of Tuesday to Thursday are reported on next Thursday. Every batch was reported as a single assay including all hormone assays. In the year $2013-2014$ from $1^{\text {st }}$ July 2013 to $30^{\text {th }}$ June 2014 a total of 100 assays results were reported including all hormones. Total of 25135 patient's 18 tests were done, of which T3 of 3884 pts, T4 of 4617 pts, FT3 of 5463 pts, FT4 of 11685 pts, TSH of 23055 pts, TG of 4112 pts, TMAb of 6 pts, TGAb of 25133 pts, TPOAb of 1102 pts, LH of 618 pts, FSH of 648 pts, Testosterone of 359 pts, Progesterone of 31 pts, Prolactin of 688 pts, Estradiol of 123 pts, PSA of 42 pts, Cortisol of 54 pts and PTH of 42 pts. See Table 4 for detail. 
Graphs are plotted as point of patients on $\mathrm{X}$-axis and hormone values on Y-axis. When the need arises, the RIA lab is also available for the performance of assays for research purposes.

\section{CONCLUSION}

After careful consideration of the local infrastructure, robustness and cost of nuclear and non-nuclear assays, it is likely that RIA. methodology will be the main workhorse of routine diagnostic services. RIA will be used as the reference method to solve problems generated by non-isotopic immunoassay. With the use of modular robotic systems and improved antibody design for short incubation assay, RIA may be modularly automated to reduce further operating cost. It will be suitable for the nationwide screening of congenital diseases and other disorders.

\section{REFERENCES}

Nuclear Medicine Resources Manual. International Atomic Energy Agency, VIENNA, 2006; 76 - 81 . 